\section{Becoming-with in a compost society - Haraway beyond posthumanism}

\section{Becoming-with in a compost society}

Federica Timeto

Department of Philosophy and Cultural Heritage, Ca' Foscari University of Venice, Venice, Italy

\begin{abstract}
Purpose - This paper considers the role of nonhuman animals in the thought of Donna Haraway, going from her critique of the animal as model/mirror for the evolution of the human body politic to her proposal for a "compost" society. It demonstrates her changing positions in relation to the social role of animals and the deepening of her critique of intersectional relations that subordinate nonhuman animals and animalized people. Design/methodology/approach - The paper intertwines a loosely historical approach and a thematic one, focusing on key issues of sociological theory, such as work, agency and kinship, and the way these relate to the animal question in Haraway's writings. Her texts are discussed both broadly and in-depth, and her positionality in terms of both feminism and antispeciesism is foregrounded.

Findings - The paper shows how the progressive abandonment of a posthuman approach in favor of a compostist one brings Haraway nearer to intersectional ecofeminism and to a fuller consideration of nonhuman agency at a material level, as well as to a deeper critique of instrumental relations of domination and issue that had been problematic in critiques of her earlier work.

Social implications - The paper highlights the role of nonhumans in the evolution and constitution of societies and advocates a response-able multispecies politics.

Originality/value - This paper offers a comprehensive analysis of the social role of animals in Haraway's thought and the deepening antispeciesism of her feminist approach that sheds a different light on her positionality in relation to ecofeminism.
\end{abstract}

Keywords Ecofeminism, Posthumanism, Donna Haraway, Animal sociology, Compost society

Paper type Research paper

\section{Introduction}

Human and nonhuman beings have always been companion species (Haraway, 2003) in a long history of coevolution. In this paper, I follow Donna Haraway's initial critique of the animal mirror in the biosocial sciences and, going through her posthuman deconstruction of the original unity of cyborg bodies, I arrive at her theory of a compost society of companion species and her proposal for a sympoietic becoming-with of the world.

Haraway's thought is paradigmatic of the way feminist animal studies have given posthumanism a more ethicopolitical impulse, also redressing the disembodiment of the linguistic turn (Salzani, 2017). Wolfe (2010) defines Haraway as a posthumanist posthumanist, together with thinkers such as Derrida and Latour as, contrary to posthumanist humanists, she questions the human/animal divide (pp. 124-126). However, during the mid-aughts, Haraway started distancing herself from posthumanists until she explicitly refused to be defined as one, standing on the side of humusities and calling herself a "compostist" instead (Haraway, 2016, p. 32).

Along this trajectory, many tenets of Western sociology - such as the very notion of society, nature and culture, interaction, family, work - were redefined according to a perspective in

(C) Federica Timeto. Published by Emerald Publishing Limited. This article is published under the Creative Commons Attribution (CCBY 4.0) licence. Anyone may reproduce, distribute, translate and create derivative works of this article (for both commercial and non-commercial purposes), subject to full attribution to the original publication and authors. The full terms of this licence may be seen at http://creativecommons.org/ licences/by/4.0/legalcode
Received 13 August 2019 Revised 20 March 2020 9 May 2020

Accepted 18 May 2020 
IJSSP

$41,3 / 4$

316

which the Human gradually lost its centrality. Haraway, who from the beginning has been interested in tracing and deconstructing the fictitious universality of a privileged kind of human (white, Western, bourgeois, male), has increasingly manifested an antispeciesist approach over time. Complicating her initial assumption that all natural bodies are historically produced, she has also come to acknowledge the inequalities and power relations intersectionally involved in the way bodies are differently produced and allowed to produce themselves. I show how her most recent theorizations $(2016,2018)$ seem to approach an intersectional ecofeminist perspective, going beyond an initial "minimally welfarist position" (Cudworth, 2016, p. 17), and argue that the compost society that Haraway envisages is a more effective proposal for undoing the relations of domination that subordinate nonhuman lives to human interests. Whereas among ecofeminists, more or less subtle differences surely exist around key issues, what ecofeminist thinkers have been stressing in contrast to universalizing theories is a situated and complex approach to nonhuman animal issues considered as social issues (see Adams and Gruen, 2014), which links intersectional analyses of multiple dominations (Cudworth, 2005) to the adoption of engaged practices like the politics of veganism.

I consider how Haraway's acknowledgment of the boundary condition of companion species, their intersectional coconstitution and coevolution and prioritization of an alien relationality in which alliances are formed out of response-ability and respect, can facilitate the implementation of a regenerative politics for living together in a multispecies world, bringing Haraway closer to ecofeminism's claims.

My text traces a path that goes from Haraway's consideration of nonhuman animals as models for reasoning about human societies to companions without which any future, liveable nature cultures would not even be conceivable. Although much of Haraway's enormous body of production will be only marginally mentioned, I hope that the reader will nonetheless be provided with the nodal concepts needed to walk further along the suggested itinerary and its side tracks. In this respect, I find it useful to invoke the strings of Haraway's cat's cradle figuration (1994). She often employs it to describe the multispecies coevolution of the worlding world, but she also proposes it as a metaphor for a multidisciplinary analytical approach in which each node becomes fundamental for a critical practice whose patterns all the players should be able to create and to be responsible for. It is an invitation to collective, compost work, which Haraway addresses as both the content and the methodology of her scholarship, and that I also employ here for its useful demystifying of assumptions, in the awareness that knots are continuously made and unmade by multiple agents in their relational entanglements.

The mirror animal, or: the animal science of the body politic as it has been [1] ...

Haraway's scholarship from the second half of the seventies addresses the boundaries that separate nature and culture, exposing natural reality as social reality with the aid of an interdisciplinary approach informed by socialist feminism and cultural studies. At this stage, her critique of the ideologies of the unmarked human concerns the human being, and her focus on nonhuman animals foregrounds the ways they have served as models for human social systems. The material-semiotic practices of primatology and their ideologies of the body politic are Haraway's main terrain of analysis during these years, merging into her book Primate Visions (1989) a decade later and the first section of Simians, Cyborgs, and Women (1991) soon afterward. Opposing nature and society, and the animal body and the social body accordingly, US primatology between the end of the First World War and the Cold War era naturalizes human history and represents nature as raw material, the ground upon which human civilization is measured, whether by evolutionary difference or continuity [2]. Primates become privileged sites for observing the "traffic in meanings" [3] (Haraway, 1989, p. 1) that subordinates certain human categories to others. Despite belonging to the primate taxonomic order, human beings exempt themselves from this traffic, benefiting from their anthropocentric exceptionalism 
[4]: an indisputable privilege from which all other differences are set, which also make scientists declare primatology a field where nature without interference can ultimately be observed.

Contrary to the diffuse demonization of technoscience among radical and ecofeminists of the period, Haraway believes that, whereas it is necessary to unmask the interests of supposedly value-free technoscience (as socialist feminists, e.g. have done regarding reproductive technologies), at the same time the role of the natural sciences in social domination and inequality cannot be underestimated lest we run the risk of maintaining the culture/nature dichotomy. Socialist feminism is Haraway's point of departure:

to investigate how the field of modern biology constructs theories about the body and community as capitalist and patriarchal machine and market: the machine for production, the market for exchange, and both machine and market for reproduction. (Haraway, 1991, pp. 43-44)

Haraway prioritizes labor as the "fundamental human condition" (1978a, p. 25) for taking into account the transformative interactions of human beings with other human beings and with the natural world and so overcomes the nature/culture dualism. In a classically Marxist (and yet humanistic) language, she writes that we constantly make ourselves through material and immaterial labor interacting with what "has not yet been humanized" (1978a). In this context, reappropriating the means of production and reproduction beyond the logic of scarcity and domination of patriarchal capitalism includes reappropriating the tools of scientific knowledge as well.

Nevertheless, Haraway never worships scientific truth as such, just as she does not believe in a return to nature as such. She prefers speaking of (science) fictions rather than facts, as fictions are always activities: not made up realities, but rather provisional ones disguised under a durable appearance [5]. Acknowledging the historicity of (science) facts does not only mean that the past always was in (for the moment just) human hands, but that the future can be too. Ultimately, we cannot do without (at least discursive) technological mediations for approaching nature. Without returning to the tricks of classical representationalism and its optical metaphors, it is impossible to "hav[e] animals, on the one hand, and statements about them, on the other, with nothing in between", as Latour puts it (2000, p. 8).

For primatologists, tools mark the appearance of the human species as the only one capable of naming itself and thus acquiring control over kinship and setting itself up against the natural body. Analogously, for Marx, history demonstrates the "developmental' process of humankind" (Benton, 1988, p. 6) as it emancipates human beings from nature, leading to a transformation of their relation to it - and eventually to defeating the capitalist order that instrumentally equates human and nonhuman animals. Freed from the alienating needs sanctioned through institutions like the family, the workplace and the state, humans can return to their social existence and follow their more proper (i.e. species-specific) inclinations. But tools can also be the cause of human alienation if they are used as means of domination rather than liberation; in fact, an unspoken consequence of the socially fulfilled human project happens to be the alienation that human beings impose upon animals as well as animalized human beings.

Haraway proposes to refocus on the mediations of labor processes to "return from the tool to the body, in its personal and social forms" (1978b, p. 38). Paraphrasing the title of the Boston Women's Health Book Collective's famous book Our Bodies, Ourselves (1973), she does not imagine a naïve return to bodily naturalness, but a different employment of tools for social liberation inside an embodied, active dimension, one that, nonetheless, is only liberating for humanity for the moment.

The biosocial sciences during the period that Haraway considers employ nature and primate bodies metonymically, as mirrors created to reflect how human beings imagine themselves, which give humans back the insights or the illusions that they need. The dualisms on which primatology rests reveal strong gender and ethnic biases, which in turn depend on a whole series of practices of speciation. Body is to mind as nature is to culture, and
Becoming-with in a compost society 
IJSSP

$41,3 / 4$

318

if the human being (or rather, man) is the only agent of civilization on the side of culture, then the nonhuman animal is to the human being as the state of nature is to social life [6]. A devaluation of nature, animality and the body follows:

What had to be managed were organic life, instinct, sex. At the top of the organism-pyramid was mind, permitting altruism to mitigate the excesses of competition ... Cooperation most certainly included rational organization of hand and head, of subordination and dominance, of instinct and mind. (Haraway, 1991, pp. 47-48)

Over the "organic base" (Haraway, 1978a, p. 30) of the modeled primate body, which demonstrates how humans could be specularly re-created, idealism meets natural science to "produce" and keep civilized humans under control, legitimating the systems that make the Spencerian social organism work smoothly and preserve the status quo, from the cell to the Nation via the cornerstone of the heterosexual family (Young, 1992): this is where "Hobbes's Leviathan has found its twentieth-century biological expression," writes Haraway (1978b, p. 45). In line with the tenets of socialist feminism, however, Haraway's return to the body is neither abstracting nor dictated by a reductionist materialism. Accordingly, actual bodies are not prisons that forbid our entrance into the body politic, nor does technoscience let us escape from a natural dimension that in no case can be accessed outside social relations.

Whether they are based on laboratory experiments or field work, whether focused on production or reproduction, domination or stress, whether psychobiologically or sociobiologically oriented, whether they come from male or female (or feminist) primatologists, the theories analyzed by Haraway all support the scientific management of society. They work descriptively and prescriptively to naturalize inequalities and maintain the systems' order according to a liberal, mechanistic-functionalist paradigm - initially focusing on personalities and later targeting populations. Female sexual receptivity enhances male competition "to accumulate the means of (re)production," that is genetic capital (Haraway, 1978b, p. 45). Males are the heads who make themselves, females are the passive resources who produce offspring and eventually create surplus value. Hunting, tool invention, food sharing and the social division of labor, consolidated by the privileged ownership of females inside nuclear heterosexual families, mark the passage from animal instincts to the cooperation on which human societies can flourish.

\section{Beyond the human: refiguring the actors}

In a couple of passages from the first part of her "Animal Sociology" articles (1978a), Haraway actually foregrounds the subjectivity of nonhuman animals and paves the way to a deeper analysis of the coconstitution of humans and nonhumans. In fact, she writes, "a liberating science of animal groups would better express who the animals are as well; we might free nature in freeing ourselves" (p. 27). In a subsequent passage, she goes even further, affirming that a liberating science is not just one that reinterprets facts and changes terminologies, but one which does not:

den[y] a dialectical interaction with the animals ... Not surprisingly, one of the first steps has been to switch the focus from primates as models of human beings to a deeper look at the animals themselves - how they live and relate to their environments in ways that may have little to do with us and that will surely reform our sense of relation to nature in our theories of the body politic. (p. 35)

Whereas, up to a certain point, the core of Haraway's critique remains the mirror-like relations of nonhuman and human individuals and societies, she then turns to a decisive acknowledgment that "animals are material-semiotic actors in the apparatus of bodily production" of sciences (1989, p. 309): in Primate Visions, in which the main focus continues to be social constructions of the human, Haraway explicitly envisages the concurrent role of nonhuman animals in performing "jointly accomplished" (p. 5) facts with the human, although the setting of animal agency is still circumscribed within the field of scientific 
observation. Moreover, in this book, Haraway more evidently addresses the histories that link nonhuman animals and inappropriate/d others (Haraway, 1992) such as women, ethnic minorities and the colonized, in relation to whom colonial primatology is poignantly defined as "simian orientalism" (Haraway, 1989, p. 10). She also dwells on the exploitation of nonhuman animals for human ends - such as when she reports on the "astro-chimps" or Harry Harlow's experiments - although such narratives ultimately shed light on the contested aims of human societies and their gender and ethnic biases more than their speciesist ones.

The role of nonhumans in the constitution of society is not explicitly formulated yet, but animals are said to possess semiotic agency, which makes them interfere epistemologically with the human realm. That is, animals are not transparent mirrors or mute projection screens, but rather dense agents that "resist, enable, disrupt, engage, constrain, and display. They act and signify, and like all action and signification, theirs yield no unique, univocal, unconstructed 'facts' waiting to be collected" (Haraway, 1989, pp. 310-311). Making it eventually clearer that being is relationality, Haraway expands the tradition of social interactionism - from which she also borrows the notion of "significant other" (Haraway, 2008, p. 15), employing it for nonhumans - which grants access to the social order through the symbolic activity of language that only humans are said to possess. Indeed, according to a posthuman post-Meadian sociology, animals act as social partners, not merely as surrogates of absent humans or projections of anthropomorphic intentions (Franklin et al., 2007) [7].

The acknowledgment that animals are capable of semiosis and communication, though not in a linguistic way (see Derrida, 2008), frees nonhuman animals from their mechanistic representation and raises the issue of animal representativity. Haraway (1992) returns to the Understanding Is Everything picture featuring the primatologist Jane Goodall's hand holding a chimpanzee's hand, a symbol of the white woman who reconciles Western civilized man with the lost Eden, to criticize the notion of "tutelage": speaking for means disengaging the spoken-for from their collectives and relying on a salvationist ideology that presupposes the nonsociality of nature. Critically quoting Marx on how animals must be represented because they are unable to represent themselves, Haraway doubts whether asking who speaks for whom is the right question, or whether it depends on a representationalism that detaches the observer as a "ventriloquist" from the observed, foreclosing an analysis of their relationality.

Animals are full-fledged "actants" in multispecies collectives, a term that, at this point, Haraway prefers to "actors," the latter still belonging to the language of liberal individualism (1992, p. 331, n. 11). Reducing animals to silent objects, as US 20th-century primatology does, precludes the articulation of relationships among humans and "unhumans" (p. 333) happening in complex and meaningful nodes in "natural social (one word) life" (1992), even though they are mediated in nonlinguistic ways. Articulation, as the ability to both recognize and produce connections, is the antidote to ventriloquism: "The articulata are jointed animals; they are not smooth like the perfect spherical animals of Plato's origin fantasy in the Timaeus. The articulata are cobbled together" (Haraway, 1992, p. 324). Articulation foregrounds differences within and without each involved actant. It thus also requires reflexively articulating one's position in the field (see also Latour, 2000): for Haraway, a politics of relationality is always also a politics of location, and vice versa (see Timeto, 2015a).

Such a plea for articulation, a concept that converges in Haraway's (2016) compositionist approach and which also resonates with Karen Barad's (2007) notion of intra-action, presupposes the cyborg's "border war" in the territories of production, reproduction and imagination (Haraway, 1991, p. 150). Haraway critiques both socialist and radical feminism for their identification of a single source of oppression for women (either class or the sex/ gender system), which incorporates the "polyvocal, unassimilable, radical difference" (p. 159) of partial subjectivities. She talks about the pleasures and responsibilities of the cyborg boundary condition. When cybernetic, genetic, immunological and network metaphors 
IJSSP

$41,3 / 4$

320

prevail in biosocial sciences during the second half of the 20th century, shifting attention to the interfaces of bodies measured according to flows rather than properties, boundaries are strategic for either transgression or social control. Somehow, cyborg bodies are caught between these two poles, as their antithetical formulations and popularizations testify (Timeto, 2015b). Traversing the emerging borderlands that follow the breakdown of the boundaries between the organism and the machine, matter and information, the human and the nonhuman, the Harawaian cyborg intends to escape the categorizations used for the management of human beings in Western postwar societies.

As a proposal for a feminist coalitional politics beyond the logics of natural identity and either class, race or gender for a univocal identification of the "we," the cyborg call for oppositional networking inside the "integrated circuit" certainly is a powerful imaginative resource (Lynes, 2015, p. 3), particularly if we consider the historical conjuncture in which it was created (detailed in Haraway and Wolfe, 2016). Among the contested categorizations is also that of "human animality" (Haraway, 1991, p. 152), which in turn relies on the machinic animality view, exemplified by Frederick W. Taylor's dream of the factory worker as trained gorilla (1947). Can posthuman cyborg couplings confer a new status on bestiality, as Haraway hopes, and ensure the same possibilities of cohabitation to all living cyborgs? Do nonhuman animals benefit from the same "apprehension ... of oppression, and so of possibility" (Haraway, 1991, p. 150) that is (in principle) granted to humans inside the "polymorphous information system" (p. 161)?

Given the manifest inequalities of human positionings in the system, as well as the mostly univocal positioning of animals in the animal-industrial complex (Noske, 1989), the promises of cyborgs have elicited many controversies [8] around their widespread political efficacy, especially if made for the project of a multispecies society. Kate Soper (1999) finds Haraway's appeal to the connectedness of all species (although she mistakes this connectedness for a natural one, which Haraway repeatedly insists it is not) equivocal and contradictory when confronted with her antinaturalist defense of technologies, also noting how it is the respect for their bodily "integrity," rather than a participation in cyborg fluidity and partiality, that suffering bodies long for (p. 171). For Soper, "the refusal to blur the machine-body boundary" (Soper, 1999) is of the utmost importance for the condemnation of torture. Soper's moral critique has an echo in Zipporah Weisberg's (2009) antispeciesist argument. The latter asserts that Haraway's "ideological cover" for such practices as "animal experimentation, genetic engineering, dog breeding and training, killing animals for food and hunting" (p. 23), all foregrounded in When Species Meet (Haraway, 2008), disguises a speciesist assumption. Such critiques later return with Josephine Donovan (2014), who also finds Haraway's critique of "purity fetishism" "outrageous" (p. 87) and considers her (and Barad's) vision of hybridity as antithetical to an engaged participatory ethics Erika Cudworth (2016) resumes this debate, reiterating that Haraway's welfarist ethics (mainly referred to Haraway, 2008) cannot be liberating for nonhuman animals, in the end, since the goal of improving the system of animal exploitation, rather than advocating for its radical dismantling, precludes intersectional analysis and political advocacy.

Moreover, while acknowledging the fundamental contribution of socialist feminism to expanding the category of work so as to include reproductive labor, and while also delving into actual forms of exploitation of female and feminized work in the integrated circuit, Haraway does not go further in considering the intersections of human and nonhuman reproductive labor that radical feminists (Corea, 1985) and ecofeminists (Adams, 1990) of the same period address.

The fact that the most iconic cyborgs are the astro-chimp implanted with telemetric devices (Haraway, 1989) and the "living invention" of the patented OncoMouse ${ }^{\mathrm{TM}}$ (Haraway, 1997) should warn us that the liberating cyborg encounter, at the same time, also masks a further separation between the human and the animal and, again, a dominion of the former 
over the latter - along the trajectory leading from the Clynes-Kline (1995) version of the cyborg to the transhuman one. In fact, even though Haraway's cyborg strongly opposes the mechanistic view of the animal organism without agency, the agricultural animal on the one hand, and the mouse implanted with an osmotic pump as proto-cyborg (Clynes and Kline, 1995) on the other, have evolved, the first in the machine-enhanced animal of industrial capitalism and factory farming; the second in the laboratory model animal.

The promising cyborg world that Haraway imagines, "in which people are not afraid of their joint kinship with animals and machines" (1991, p. 154), and in which all agents enjoy their partial identities, does not encompass "industrial livestock" whose lives in cyborg assemblages undergo a bodily colonization that forbids their symmetrical participation in society from before they are born (through genetic modifications). For such beings, the boundary's erasure rather signals the ontological collapse (Weisberg, 2015, p. 39) that they experience when they are systematically produced and dismembered to become goods, or some of their parts are highly functionalized for the unending cycle of production and reproduction.

"Refiguring the actors" (Haraway, 1992, p. 297) that are not all us, as well as unmasking the social and power relations at play in the networks, whose animal bodies are material-semiotic nodes, is surely an important step toward the achievement of a nature culture that "has many houses with many inhabitants which/who can refigure the Earth" (Haraway, 1992). However, a transformative approach toward a multispecies body politic needs to be effectively rooted in the singularity and intersections of human and nonhuman lives, where the material interference of other animals needs to be respected. Respect does not only mean giving another look beyond the speciesist gaze; it also means layering the ontoepistemological plane with a sociopolitical dimension: paying attention, meeting respectfully, regardless of species, is the basis for the constitution of the polis (Haraway, 2008, pp. 19, 164).

Whereas Derrida (2008) looked at his cat wondering what would happen if the animal responded, Haraway (2008) believes that not only do animals respond, and that listening to them matters, but that they also ask questions from and about their positionings, interrogating the human-animal relations from their situated standpoint. Altering these relations is a matter of embodied actions, not merely of meanings. As Jason Hribal (polemically) writes, picking up from where Haraway left off: "To our original question: Can animals be biotechnology? The short answer is, yes. But the long answer is, why?" (2012, p. 15). This is a question that nonhuman animals pose to humans every day.

\section{From listening to animals' responses, to answering animals' questions}

Developing a multispecies sociology requires that some key concepts of sociological analysis, starting from society itself, be reconceptualized so that nonhuman beings are respected. Carter and Charles (2018), for example, make the case for a notion of agency in a way that is very near to Haraway's view: reformulated not in terms of an inner property of the human self and intentionally exerted on an outside "reality," but rather as emergent in contextual relations, agency is distributed in "overlapping webs of agential conditions" (p. 92) involving social agents, without exceptions. Haraway shares this "performative," antiessentialist, approach to the social, which displaces the social from its exclusive location in human beings and locates it in interspecies doings. Calling for a performative approach to animal sociology, Strum and Latour (1987) note that the first meaning of the word "social" originally was "association," beyond the requirement of commonalities or contracts. Neither human nor animal, the social is the order - or disorder - emerging in performative interspecies meetings, which are not socially predictable (see Barad, 2012; Birke et al., 2004). This focus on performativity can also explain why Haraway continues to stress the importance of working relations, even though, in time, she moves away from socialist feminism.
Becoming-with in a compost society 
IJSSP

$41,3 / 4$

322

In one of the most highly debated passages of her work, Haraway (2008) says that relations of use are inescapable among all living beings and even evokes a "zoological Marx" (p. 72) to contest the idea that animal freedom is the mere absence of necessity or work: animals are not only worked but also working subjects (p. 80). Talking about dogs, she writes:

[D]ogs have become patients, workers, technologies, and family members by their action, if not choice, in very large industries and exchange systems in lively capital: (1) pet foods, products, and services; (2) agribusiness; and (3) scientific biomedicine. (p. 62, author's italics)

But what kind of work is animals' work, when it is unwaged and certainly not selfdirected, as in all these sectors? Which kind of agency can agency without choice be? If people and dogs are "mutually adapted partners in the naturecultures of lively capital" (Haraway, 2008), (p. 55) then a double-sided socioeconomic relationship like work requires a symmetrical perspective (Hribal, 2012).

This is a very urgent issue in the current "age of bioeverything" (Herzig and Subramaniam, 2017). Currently, value can potentially be extracted from every form of life; the alienation of bodies from the value of their reproductive labor finds in factory farming a paradigmatic example of efficiency - along with the interspecies intersections of oppression among laboring bodies. The more flexible the category of labor becomes, the more a liberating approach to it cannot disregard the asymmetrical relations of power. These affect working subjects differently according to their class, history, geography, sexuality, gender and, not secondarily, species: "If we aim to understand contemporary 'vital politics', in other words, we have much to gain by considering those labours deemed 'trivial' and lives deemed worthless" (ivi, p. 116). Actually, this leads Haraway from the still unaddressed issues of The Companion Species Manifesto (CSM, 2003) to a more open acknowledgment that an affirmative biopolitics must address nonhuman lives. And without fear of using words such as genocide also for nonhuman animals reduced to "forced-life machines" (Haraway and Wolfe, 2016, p. 229; see also Dal Lago et al., 2018).

Devoid of the humanistic privilege of sufficient reasons in instrumental relationships with nonhuman animals (Haraway, 2008, p. 76), we cannot ignore that, on a very mundane and global plane, inequalities, suffering and domination in interspecies work relationships prevail and that, notwithstanding our "mortal entanglements" with the nonhuman (p. 226), we most often ignore the relations of obligation that such entanglements present us with (Barad, 2007). Precisely because response-ability does not end at abstract calculation but is always "crafted in intra-action," as Haraway emphasizes (2008, p. 71), always materially performed, it entails changing one's actions. Response-ability must infect meanings and practices (Haraway, 2016, p. 114). It does not simply mean putting oneself in the position of the other, perpetuating the idea of philanthropic protection that does not exit from the self and is also disempowering for the represented animals - both in dominating ideologies and in animal rights discourses. It rather means being both subjects and objects to each other, all equipped with a symmetrical possibility of being capable together of transforming the constraints that limit this possibility [9].

Since living bodies are subordinated and exploited along several intersecting axes that most often presuppose the human/animal dichotomy, and because oppression is improperly deemed in-human, that is, without humanity [10], an intersectional antispeciesist politics requires a symbiotic rather than chimeric (feminoska, 2019) politics of alliances. As cyborgs, we could be chimeras (Haraway, 1991, p. 150), hybrid assemblages of partial selves, as companion species [11] (messmates at the same table, from the Latin etymology cum panis), we are symbionts, "entwined non additive subsystems" (Haraway, 2016, p. 43). To counter the ideology of evolution as a process of the separation of the human from and above other animals and nature, Haraway borrows the notion of symbiogenesis, mentioned in "The Promises of Monsters" (1992) and in CSM, but central in her writings from When Species Meet (2008). 
Symbiogenesis, a process that involves micro- and complex organisms, as the humancanine kiss that opens CSM manifests, was first theorized by the Russian botanist Konstantin Mereschkowski at the beginning of the 20th century and then disseminated by the biologist Lynn Margulis toward the end of the sixties. In brief, it affirms that eukaryotes (organisms whose cells have a nucleus) evolved from a symbiosis with prokaryotes, unicellular organisms whose cells lack a nucleus, such as bacteria and archaea. For the sake of our argument, it suffices to say that this theory, according to which every animal becomes-with bacteria in the first instance - not only contests the evolutionary vocabulary centered on conflict, cost/benefit and the Neo-Darwinist fetishization of genes, but also highlights how evolution is not a matter of hierarchical dominance and vertical filiation of the Same, but the outcome of lateral transformations, assimilations, digestions and ejections through which living beings materially compose and decompose, live and die together [12].

Cyborgs raise questions about history and society; they are also privileged sites for ethnographic inquiry about individual and collective agency in technoscience networks. Where cyborgs uncover the cracks and splices of subjective formations, companion species such as symbionts cultivate "kinship work in action" (Haraway, 2008, p. 67). With companion species - for which the category is not even really defined, being permanently under construction - the focus is put on actions that range from individuals in environments to those of entangled ecosystems: "never purely themselves" (p. 250), companion species become-with companion species (pp. 164-165) in a chain without origin or ending, inheriting and transforming reciprocal histories together. They form compositions in which the social appears as always already ecological, in which no "natural" being exists that is not endowed with agency and can generate and modify social relations. In such ecologies, there exist neither fully predetermined behaviors nor fully self-contained ones.

\section{Inhabiting a compost society}

Multispecies becoming-with is, for Haraway, "a much richer web to inhabit than any of the posthumanisms on display after (or in reference to) the ever-deferred demise of man" (2006, p. 99). In fact, companion species encounters defy both the inclusive/exclusive binary of humanism and the identity/difference binary of (much) posthumanism. Most importantly, companion species escape analogies, distancing from the animal as model/mirror: they are intersectional beings and solicit an intersectional reframing of their production and reproduction along multiple axes of domination (Haraway, 2004, 2016, 2018; Cudworth, 2005). Here, Haraway's reflections meet those of ecofeminists, though arriving from slightly different paths and at times still diverging on some points [13].

Even though a detailed comparison between the ideas of Haraway and ecofeminists (including a consideration of the different positions among the latter, for which see Gaard, 2011) exceeds the scope of this essay, a few points are worth mentioning. Both Haraway (1991) and ecofeminists (Donovan, 2006, 2014) embrace situated epistemologies and a politics of location; however, ecofeminists soon disclose the speciesist biases of the utilitarian approach to animals (Singer, 1975), which allows them to adopt a dialogical theory of care, granting nonhuman animals what Haraway (2008) would later call response-ability; already in the early 1990s, such interspecies ethics and politics rested on an intersectional approach, notwithstanding several misunderstandings and often going unacknowledged (Gaard, 2011). Haraway, who shares with ecofeminists a critique of animal rights discourses while distancing herself from socialist feminism over time (Haraway, 1991), does not completely refuse a utilitarian approach to human relations with nonhuman animals but only excludes the calculation of "sufficient reasons," opting for what she calls "felt reasons" instead (Haraway, 2008, p. 76) [14]. Because of this, she never embraces political veganism as most ecofeminists do (Adams and Gruen, 2014). In any case, I argue that after theorizing 
IJSSP

$41,3 / 4$

324

companion species as social agents, Haraway's consideration of symbiogenetic processes reconceives social formations in a manner that paves the way to practicing an intersectional politics of alliances in a composite, multispecies body politic, getting closer to the claims of ecofeminism.

A society of companion species composes - and decomposes - as compost, finally burying under the ground, in the humus, the human body politic that has always elevated itself above the body of nature, which sometimes the "not made of mud" cyborg body (Haraway, 1991, p. 151) has been mistakenly conflated with (see Timeto, 2015b) [15]. If primatology was exemplary of how the encounter between the social and the natural sciences created a gap between society and nature, molecular biology offers a nondisjunctive perspective to consider the link between the fields and society and nature accordingly. Compost, as the work of this unending meeting of beings that is sympoiesis (2008, p. 287) [16], is an in actu example of a multispecies assembling that is open and respecting without being inclusive or exclusive which renders compost societies' worldling as flourishing as it is risky (Haraway, 1991, p. 214).

Not every partner brings the same story and has the same weight in compost work: some are in the position of being more able to respond than others in some encounters, and it is their responsibility to be as responsible as they can. Rather than considering the consortia of microorganisms as a model for the structure of human societies, Haraway looks at the dynamics that relate multiple lives in compost. Not all lives (including quasi-lives, such as viruses) are equivalent, but all lives are present in Terrapolis (Haraway, 2016, p. 11), "an operator of mise en égalité," to use Isabelle Stengers's words (2005, p. 995). This also means that no designated representatives of the collective, stating what can be decided and what counts, exist in advance, which renders each decision as co(i)mplicated as possible.

Compost societies are mobile and hospitable; they cultivate queer kinship, they strive for the Common. Traditionally, the way borders are defined and defended explains how societies are conceived and how they can be transformed (Rumford, 2006). Some examples in Haraway's texts include an analysis of the colonial and militarized ideology of the immune system, built around such dichotomies as alien/familiar, polluting/pure, invasion/defense (Haraway, 1991, 1997), and the notion of invasive animal species (Haraway and Wolfe, 2016, p. 235), extended so as to sociospatially exclude unwanted people, like the homeless or migrants (see also Jerolmack, 2008): both are employed as strategies to defend the symbolic and material propriety of the individual as, for example, Joost Van Loon (2000) shows, underlining the historical links between xenophobia and the containment of epidemics.

Not only are compost communities (Haraway, 2016) troubling for the maintenance of clear borders, happening in alien relationalities, right where the opening of boundaries takes place, but they also practice "corridor thinking" (2016, p. 218, n. 8) and build passages that allow symbionts to travel and flourish in movement - migratory species, like the monarch butterflies for the Camilles of The Camille Stories (Haraway, 2016), often shape their partners in symbiosis. Compost communities can also be healing and restorative in the case, for instance, of forced displacements or genocides: not built from scratch, not imposed from above (according to a colonizing logic), they take place among inherited ruins, in which they cultivate hospitable refugia as "a basic obligation and source of mutual renewal" (p. 147) for rebalancing inequalities and losses.

Writing in 1975, Rubin said that it was time for feminism to "call for a revolution in kinship" (p. 199). Haraway echoes and expands on Rubin's ideas when she eventually reconsiders the links of production and reproduction from an intersectional and interspecies perspective (Haraway, 2018). Companion species queer blood lineages and legitimate unions, troubling the categories of kinship and kind (see also Barad, 2012) and the institutions at the heart of the purity dream of the Modern Western subject. Coevolving in unfamiliar genealogies, they disrupt the social model of the oikos (Haraway, 1991, p. 151), the nuclear (heterosexual) family and the familial community, which primatology saw as the basis of 
human evolution and which the cyborg started unraveling by replacing reproduction with regeneration.

The constitution of compost societies depends on a generation of life and relationships that are neither genetic nor reproductive in the "natural" sense; kinship is redefined as oddkin, a nonnatalist (rather than antinatalist) category that calls for "breaking the necessity of the tie between kinship and reproduction" (Haraway, 2016, p. 216, n. 4) and looking at intersectional complexities in contact zones. Thus, for instance, the appeal to relate human and nonhuman animals in statistical measures of population - already a problematic, exclusionary, category (Murphy, 2018) - which can nonetheless be used, says Haraway, provided that we open it up along its differential axes for multispecies reproductive justice: both for the Born, who lack the privileges granted to "valuable" over "expendable" lives and including the beings forced to life, such as animals in factory farming, and for the Disappeared, or those forced to death, like indigenous groups, missing and trafficked people, the unable to be born, the exterminated and the extinct (Haraway, 2018).

"Kin-making is making persons, not necessarily as individuals or as humans" (ivi, p. 92), which, for Haraway, requires "pro-ongoingness in our mortality, not pro-Life" (Haraway and Wolfe, 2016, p. 236). Although the slogan "Make Kin Not Babies" (Haraway, 2016, p. 102) can appear problematic in some respects (see Hamilton, 2019), Haraway does not oppose natural reproduction per se, but considers it a community responsibility rather than an individual choice and prompts us to imagine kin as a distributed commitment instead. Inviting feminists to start from disentangling existing, presumedly natural, configurations and account for the "specificities, priorities and urgencies" (2016, p. 207, n. 12) of their various strings, she longs for a multispecies ecofeminism in which relatives and relations are not inherited, observed or reproduced as such, but reassembled and continuously cultivated across differences and specificities and beyond the boundaries of kin and kind.

The adoption of a "situated" utilitarian perspective led Haraway (2008) to affirm that the issue is not so much not killing, but not making killable, meaning not differentiating in principle between murderable and merely killable or disposable species. Confronted with the project of a compost society, this difficult to share position - albeit consistent with Haraway's assumptions at that point - enriches itself with a more complex and response-able approach to life and death: not only can we not deem certain species killable in advance, but we first of all share a responsibility not to let them or force them to die, as well as to not force them to live (often to only make them die later, as in the case of farmed animals). Then, when Haraway $(2016,2018)$ affirms that she is not pro-Life [17], she is not saying that she is antinatalist tout court. She invites us to complicate the frame beyond a simple yes/no and personal alternative, and to consider from an intersectional and compostist perspective, which lives and deaths we see and sustain, which lives and deaths happen or not, where and under what conditions.

I do not think that Haraway's thought lacks analyses of the material and discursive networks that justify animal exploitation through speciesism, as the OncoMouse ${ }^{\mathrm{TM}}$ story (Haraway, 1997) makes clear, or that it is comparable to a purely philosophical celebration of the "becoming animal" of authors like, say, Braidotti or Deleuze and Guattari. I do think, however, that in time she has distanced herself from a more analytical plane and further problematized her own perspective on instrumental interspecies relations. In fact, she elaborates on how the speciesist assumptions of these relations often rest on the very technologies celebrated by the cyborg as liberating, but which are almost only for human cyborgs. Thus, they not only subordinate nonhuman animals to human aims and preclude a symmetrical consideration of agencies, but also justify intra-human domination (Cudworth, 2011). The more decisive move towards antispeciesism does not result in a complete abandonment of what she calls a non-innocent position. Instead, it gives rise to a more explicit call to build a multispecies compost society, drawing on the analyses of concrete situations
Becoming-with in a compost society

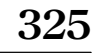


IJSSP

$41,3 / 4$

326

and current urgencies and considering the inter- and intraspecies relations among the multiple agents involved (Haraway, 2016, 2018).

Haraway's intention to keep the dialogue with ecofeminism open (Haraway, 1991, 1992, 2008,2018 ) has not found equal correspondence (but see Plumwood, 1993) among ecofeminists (Adams, 1995; Adams and Tyler, 2006; Donovan, 2014; Gruen, 2014). Notwithstanding the similarities outlined earlier, Haraway's defense of technoscience still appears at odds with an ecofeminist perspective. This, however, requires a duplicitous clarification.

As I have explained here, Haraway increasingly problematizes the use of technologies of domination and the domination of animals as living technologies, questioning the instrumental relations between humans and nonhumans and extending the consideration of social agency to companion species, even when and even though she does not exclude that nonhuman animals can also benefit from the advancements of technoscience [18]. Haraway acknowledges the silliness of technoapocalypses as well as technofixes that Anthropocene narratives evoke (2016, p. 3) and maintains the importance of situated technologies for staying with the troubles of our times. Alongside this, we can say that Haraway has always approached the issue of technology more broadly, leading us to reflect on the "technological" constitution of all nature cultures. A denaturing artifactualism (Haraway, 1991) is the ability to produce (outside humanist productionism) and articulate relations that are not in any way madeup, but are indeed made, a condition that compost dynamics materialize.

Comparing cyborg feminism and ecofeminism, Stacy Alaimo (1994) observes that an ecofeminist approach should ground "affinity in politics" rather than "politics in affinity" (p. 150), that is composing alliances without identities as their source or goal. Multispecies compost societies, as Haraway imagines them, indicate how this works and can be cultivated amid the damaged ecologies of our times. Being aware of the heterogeneous configuration of the world, we can take charge of its continuous heterogenesis. Starting from socialist feminism and arriving at compostism, Haraway eventually foresees the constitution of a symbiotic body politic, a compost society, in which the Common is doing without Being (Latour, 2010b): an ongoingness happening in the middle, and in the muddle, of sympoietic involutions.

\section{Notes}

1. The statement in italics is a quote from Haraway (1978a, p. 27).

2. At the same time, sociology defines society, the object of its analysis, as the realm of human interaction (see Carter and Charles, 2018).

3. This statement echoes a renowned essay by Gayle Rubin (1975) dealing with the subordination of women to the institution of the heterosexual family and kinship.

4. Regarding the dominant Western worldview that renders sociology anthropocentric and unecological, grounded on a paradigm of human exceptionalism that is also exemptionalist, see Catton and Dunlap (1980).

5. Haraway seems to anticipate what Latour (2010a) says about factishes here. However, apart from the many similarities between them, Haraway also criticizes Latour for being insufficiently attentive to organic nonhuman actors in his imagining of collectives, which for this reason she calls “impoverished" (1992, p. 332, n. 14).

6. The American psychologist Robert Yerkes's career is exemplary for understanding this link between the natural and social sciences: apart from studying primates, after the First World War, Yerkes worked for the National Academy of Sciences within the National Research Council in Washington, where biomedical and social problems were studied in correlation; he was also appointed Chairman of the Committee on Scientific Aspects of Human Migration, for two years (1922-1924), and of the Rockefeller Foundation-funded Committee for Research on Problems of Sex, for 25 years (1922-1947). Also, as Chairman at the 1920 annual meeting of the Personnel Research 
Federation, he declared that personnel research was the key discipline (Haraway, 1989). Yerkes, who studied primates according to the parameter of intelligence, also invented the test that was used for army recruitment in the First World War - and that would be also used to "contain" immigration afterward.

7. The article also contains a useful reference list on post-Maedian sociology concerning animals.

8. A first comprehensive debate around the feminist cyborg can be found in Kirkup et al. (2000). A more recent review can be found in Lynes (2015).

9. Unfortunately, the importance attributed to symmetrical response-ability makes Haraway's consistent, although not always shareable, "utilitarian" position on killing animals problematic. Apparently, for Haraway, causing animals suffering, as well as killing them, cannot be resolved once and for all, but always requires a situational, noninnocent (conversely, also nonguilty?) evaluation of the specificity of any killing (Haraway, 2008, pp. 69 ff.). This killing, she calls it (Haraway and Wolfe, 2016, p. 233). In any case, justifiable suffering and responsible killing - killing as best as possible (p. 227) - sounds, at best, oxymoronic.

10. A term used often considering the "animalizing" consequences but not the very human reasons. On the speciesist biases of animal metaphors in language, see Adams (1990).

11. CSM only includes animals forming workforce or family with humans, according to a logic of domestication that does not fully address other "complex interrelations of difference-in-domination" (Cudworth, 2005, p. 155), an issue that Haraway addresses in her later texts (2016, 2018).

12. The use of symbiogenesis in the social ecology of Murray Bookchin leads to a different conclusion, as discussed in Cudworth (2005).

13. Apart from recalling the foundational theorists of intersectionality, Haraway (2006) shows her debt to Adams (1995) for her intersectional nonanalogical perspective. In a recent interview, she again pays homage to Adams and to the oppositional politics of veganism in the end, although she feels "in allied friction" with her (Franklin, 2017, p. 56).

14. In this respect, Haraway's position and the "contextual moral vegetarianism" of Curtin (1991) could be interestingly compared.

15. Indeed, somewhere along the way, Haraway confesses to being "a creature of the mud not the sky" herself (2008, p. 3), constantly becoming-with her visible and invisible companions.

16. A term originally coined by Beth Dempster, a student of Haraway, at the end of the 1990s, which Haraway uses to counter the idea that systems are autopoietic (Haraway, 2016, p. 33; p. 61).

17. A fruitful comparison can be made between the pro-choice positions of Adams (2016) and Haraway (2016, 2018).

18. An example is when she discusses the hormonal therapies for her and her menopausal dog and, at the same, time retraces the multispecies exploitations of Premarin (Haraway, 2016).

\section{References}

Adams, C.J. and Gruen, L. (2014), “Groundwork”, in Adams, C.J. and Gruen, L. (Eds), Ecofeminism. Feminist Intersections with Other Animals on Earth, Bloomsbury, New York, NY, pp. 7-36.

Adams, C.J. and Tyler, T. (2006), "An animal manifesto: gender, identity, and vegan-feminism in the twenty-first century", Parallax, Vol. 12 No. 1, pp. 120-128.

Adams, C.J. (1990), The Sexual Politics of Meat: A Feminist-Vegetarian Critical Theory, Continuum, London and New York.

Adams, C.J. (1995), Neither Man Nor Beast: Feminism and the Defense of Animals, Continuum, London and New York.

Adams, C.J. (2016), "Abortion and animals: keeping women in the equation" in Adams, C.J. (Ed.), The Carol J. Adams Reader. Writings and Conversations 1995-2015, Bloomsbury, New York, NY, pp. 287-292. 
IJSSP

$41,3 / 4$

328

Alaimo, S. (1994), "Cyborg and ecofeminist interventions: for an environmental feminism", Feminist Studies, Vol. 20 No. 1, pp. 133-152.

Barad, K. (2007), Meeting the Universe Halfway: Quantum Physics and the Entanglement of Matter and Meaning, Duke University Press, Durham.

Barad, K. (2012), "Nature's queer performativity", Women, Gender and Research, Vol. 2012 Nos 1-2, pp. 25-53.

Benton, T. (1988), "Humanism = speciesism. Marx on humans and animals", Radical Philosophy, Vol. 50, Autumn, pp. 4-18.

Birke, L., Bryld, M. and Lykke, N. (2004), “Animal performances”, Feminist Theory, Vol. 5 No. 2, pp. 167-183.

Boston Women's Health Book Collective's (1973), Our Bodies, Ourselves, Simon \& Schuster, New York, NY.

Carter, B. and Charles, N. (2018), "Animals, agency and resistance”, Journal for the Theory of Social Behaviour, Vol. 43 No. 322, doi: 10.1111/jtsb.12019 (accessed 12 August 2019).

Catton, W.R. and Dunlap, R.E. (1980), "A new ecological paradigm for post-exuberant sociology", American Behavioral Scientist, Vol. 24 No. 1, pp. 15-47.

Clynes, M.E. and Kline, N.S. (1995), "Cyborgs and space", in HabelsGray, C. (Ed.), The Cyborg Handbook, Routledge, London, New York, pp. 29-33.

Corea, G. (1985), "How the new reproductive technologies could be used to apply the brothel model of social control over women”, Women's Studies International Forum, Vol. 8 No. 4, pp. 299-305.

Cudworth, E. (2005), Developing Ecofeminist Theory. The Complexity of Difference, Palgrave Macmillan, New York, NY.

Cudworth, E. (2011), Social Lives with Other Animals. Tales of Sex, Death and Love, Palgrave Macmillan, New York, NY.

Cudworth, E. (2016), “A sociology for other animals: analysis, advocacy, intervention”, International Journal of Sociology and Social Policy, Vol. 36 Nos 3/4, pp. 242-257.

Curtin, D. (1991), “Toward an ecological ethic of care", Hypatia, Vol. 6 No. 1, pp. 60-74.

Dal Lago, A., Filippi, M. and Volpe, A. (2018), Genocidi Animali, Mimesis, Milan.

Derrida, J. (2008), The Animal that Therefore I Am, Fordham University Press, New York, NY.

Donovan, J. (2006), "Feminism and the treatment of animals: from care to dialogue", Signs, Vol. 31 No. 2, pp. 305-329.

Donovan, J. (2014), "Participatory epistemology, sympathy, and animal ethics", in Adams, C.J. and Gruen, L. (Eds), Ecofeminism. Feminist Intersections with Other Animals on Earth, Bloomsbury, New York, NY, pp. 75-90.

feminoska (2019), "Lo sguardo neutrale non esiste. Antispecismo e intersezionalità", in Bertuzzi, N. and Reggio, M. (Eds), Smontare la gabbia. Anticapitalismo e Movimento di Liberazione Animale, Mimesis, Milan, pp. 95-117.

Franklin, A., Emmison, M., Haraway, D. and Travers, M. (2007), "Investigating the therapeutic benefits of companion animals: problems and challenges", Qualitative Sociology Review, Vol. III No. 1, pp. 42-58.

Franklin, S. (2017), "Staying with the manifesto: an interview with Donna Haraway", Theory, Culture and Society, Vol. 34 No. 4, pp. 49-63.

Gaard, G. (2011), "Ecofeminism revised. Rejecting essentialism and re-placing species in a material feminist environmentalism", Feminist Formations, Vol. 23 No. 2, pp. 26-53.

Gruen, L. (2014), "Facing death and practicing grief", in Adams, C.J. and Gruen, L. (Eds), Ecofeminism. Feminist Intersections with Other Animals on Earth, Bloomsbury, New York, NY, pp. 127-141.

Hamilton, J.M. (2019), "The future of housework: the similarities and differences between making kin and making babies", Australian Feminist Studies, Vol. 34 No. 102, pp. 468-489. 
Haraway, D. and Wolfe, C. (2016), "Companions in conversation”, in Haraway, D. (Ed.), Manifestly Haraway, University of Minnesota Press, Minneapolis, MN, pp. 199-298.

Haraway, D. (1978a), "Animal sociology and a natural economy of the body politic, part I: a political physiology of dominance”, Signs, Vol. 4 No. 1, pp. 21-36.

Haraway, D. (1978b), "Animal sociology and a natural economy of the body politic, part II: the past is the contested zone: human nature and theories of production and reproduction in primate behavior studies", Signs, Vol. 4 No. 1, pp. 37-60.

Haraway, D. (1989), Primate Visions. Gender, Race and Nature in the World of Modern Science, Routledge, New York, NY.

Haraway, D. (1991), Simians, Cyborgs, and Women: The Reinvention of Nature, Routledge, New York, NY.

Haraway, D. (1992), "The promises of monsters. A regenerative politics for inappropriate/d others", in Grossberg, L., Nelson, C. and Treichler, P.A. (Eds), Cultural Studies, Routledge, London, pp. 295-337.

Haraway, D. (1994), "A game of cat's cradle: science studies, feminist theory, cultural studies", Configurations, Vol. 2 No. 1, pp. 59-71.

Haraway, D. (1997), Modest_Witness@Second_Millennium. FemaleMan $\mathbb{C} \_M e e t s \_O n c o M o u s e^{\mathrm{TM}}$ : Feminism and Technoscience, Routledge, New York and London.

Haraway, D. (2003), The Companion Species Manifesto, Dogs, People and Significant Otherness, Prickly Paradigm Press, Chicago, IL.

Haraway, D. (2004), "Cyborgs to companion species: reconfiguring kinship in technoscience", in Haraway, D. (Ed.), The Haraway Reader, Routledge, London and New York, pp. 295-320.

Haraway, D. (2006), “Encounters with companion species”, Configurations, Vol. 14 Nos 1-2, pp. 97-114.

Haraway, D. (2008), When Species Meet, University of Minnesota Press, Minneapolis, MN.

Haraway, D. (2016), Staying with the Trouble. Making Kin in the Chtulucene, Duke University Press, Durham and London.

Haraway, D. (2018), "Making kin in the Chthulucene: reproducting multispecies justice", in Clarke, A. and Haraway, D. (Eds), Making Kin Not Population, Prickly Paradigm Press, Chicago, IL, pp. 67-99.

Herzig, R. and Subramaniam, B. (2017), "Labor in the age of 'bio-everything", Radical History Review, Vol. 2017 No. 127, pp. 103-124.

Hribal, J. (2012), “Animals are part of the working class reviewed”, Borderlands, Vol. 11 No. 2, pp. 1-37, available at: http://www.borderlands.net.au/vol11no2_2012/hribal_animals.pdf.

Jerolmack, C. (2008), "How pigeons became rats: the cultural-spatial logic of problem animals", Social Problems, Vol. 55 No. 1, pp. 72-94.

Kirkup, G., Hovenden, F., Janes, L. and Wooward, K. (2000), The Gendered Cyborg: A Reader, Routledge, London and New York.

Latour, B. (2000), “A well-articulated primatology. Reflexions of a fellow-traveller”, in Strum, S. and Fedigan, L. (Eds), Primate Encounters, University of Chicago Press, Chicago, IL, pp. 358-381.

Latour, B. (2010a), On the Modern Cult of the Factish Gods, Duke University Press, Durham and London.

Latour, B. (2010b), “An Attempt at a 'compositionist Manifesto", New Literary History, Vol. 2010 No. 41, pp. 471-490.

Lynes, K. (2015), "Cyborgs and virtual bodies", in Disch, L. and Hawkesworth, M. (Eds), The Oxford Handbook of Feminist Theory, Oxford University Press, Oxford, available at: https://www. oxfordhandbooks.com/view/10.1093/oxfordhb/9780199328581.001.0001/oxfordhb-9780199328581-e-7 (accessed 20 March 2020).

Murphy, M. (2018), “Against population, towards afterlife”, in Clarke, A. and Haraway, D. (Eds), Making Kin Not Population, Prickly Paradigm Press, Chicago, IL, pp. 101-124. 
IJSSP

$41,3 / 4$

Noske, B. (1989), Humans and Other Animals: Beyond the Boundaries of Anthropology, Pluto Press, London.

Plumwood, V. (1993), Feminism and the Mastery of Nature, Routledge, London and New York.

Rubin, G. (1975), "The traffic in women: notes on the political economy of sex", in Reiter, R.R. (Ed.), Toward an Anthropology of Women, Monthly Review Press, New York and London, pp. 157-210.

Rumford, C. (2006), “Theorizing borders”, European Journal of Social Theory, Vol. 9 No. 2, pp. 155-169.

Salzani, C. (2017), "From post-human to post-animal. Posthumanism and the "animal turn", Lo Sguardo. Rivista di filosofia, Vol. 2017, pp. 97-109.

Singer, P. (1975), Animal Liberation. A New Ethic for Our Treatment of Animals, New York Review Book, New York, NY.

Soper, K. (1999), "Of OncoMice and FemaleMen: Donna Haraway on cyborg ontology", Women: A Cultural Review, Vol. 10 No. 2, pp. 167-172.

Stengers, I. (2005), "The Cosmopolitical proposal”, in Weibel, P. and Latour, B. (Eds), Making Things Public: Atmospheres of Democracy, The Mit Press, Boston, MA, pp. 994-1003.

Strum, S.S. and Latour, B. (1987), "Redefining the social link: from baboons to humans", Vol. 26 No. 4, pp. 783-802.

Taylor, F.W. (1947), Scientific Management. Comprising Shop Management. The Principles of Scientific Management. Testimony before the Special House Committee, Harper \& Brothers, New York and London.

Timeto, F. (2015a), Diffractive Technospaces. A Feminist Approach to the Mediations of Space and Representation, Routledge, London.

Timeto, F. (2015b), "Uno è troppo poco ma due sono troppi. Ovvero il cyborg come non rappresentazione", in Bianchi, A. and Leghissa, G. (Eds), Mondi Altri, Mimesis, Milan, pp. 121-134.

Van Loon, J. (2000), "Parasite politics: on the significance of symbiosis and assemblage in theorizing community formations", in Pierson, C. and Tormey, S. (Eds), Politics at the Edge, Macmillan, London, pp. 241-253.

Weisberg, Z. (2009), "The broken promises of monsters: Haraway, animals and the humanist legacy", Journal for Critical Animal Studies, Vol. VII No. II, pp. 22-62.

Weisberg, Z. (2015), "Biotechnology as end game: ontological and ethical collapse in the "biotech century", Nanoethics, Vol. 2015 No. 9, pp. 39-54.

Wolfe, C. (2010), What Is Posthumanism, University of Minnesota Press, Minneapolis, MN.

Young, R.M. (1992), "Science, ideology and Donna Haraway", Science As Culture, Vol. 3 No. 2, pp. 165-207.

\section{Corresponding author}

Federica Timeto can be contacted at: federica.timeto@unive.it

For instructions on how to order reprints of this article, please visit our website:

www.emeraldgrouppublishing.com/licensing/reprints.htm

Or contact us for further details: permissions@emeraldinsight.com 